\title{
Some Comments on the Concept of the Ego-Ideal
}

Gurmeet Kanwal, MD

Brookdale Hospital (SUNY Downstate) Brooklyn, New York

Follow this and additional works at: https://jdc.jefferson.edu/jeffjpsychiatry

Part of the Psychiatry Commons

Let us know how access to this document benefits you

\section{Recommended Citation}

Kanwal, MD, Gurmeet (1988) "Some Comments on the Concept of the Ego-Ideal," Jefferson Journal of Psychiatry. Vol. 6 : Iss. 2 , Article 3.

DOI: https://doi.org/10.29046/JJP.006.2.001

Available at: https://jdc.jefferson.edu/jeffjpsychiatry/vol6/iss2/3

This Article is brought to you for free and open access by the Jefferson Digital Commons. The Jefferson Digital Commons is a service of Thomas Jefferson University's Center for Teaching and Learning (CTL). The Commons is a showcase for Jefferson books and journals, peer-reviewed scholarly publications, unique historical collections from the University archives, and teaching tools. The Jefferson Digital Commons allows researchers and interested readers anywhere in the world to learn about and keep up to date with Jefferson scholarship. This article has been accepted for inclusion in Jefferson Journal of Psychiatry by an authorized administrator of the Jefferson Digital Commons. For more information, please contact: JeffersonDigitalCommons@jefferson.edu. 


\title{
Some Comments on the Concept of the Ego-Ideal
}

\author{
Gurmeet Kanwal, M.D.
}

In a review of the literature on the ego-ideal my impression has been that this concept has been placed in the position of a stepchild of the structural model of the mind, falling somewhere between the ego and the super-ego, and yet remaining loosely linked to both. Authors such as Jacobson (1954), Hartmann and Lowenstein (1962), Sandler (1963), and Schafer (1967), have regarded the ego-ideal as a substructure of the super-ego. Others like Annie Reich (1953, 1954), Lampl de-Groot (1947), Peter Blos (1972), and Chasseguet-Smirgel (1975), have tended to view the two as being separate structures.

The purpose of this paper is, first, to point to the value of viewing the ego-ideal from a metapsychological standpoint as a distinct entity, separate in more than one way from the super-ego. Secondly, the literature shows that many analysts tend to reduce the ego-ideal to a 'model' that the person is trying to emulate. This is not so. If we follow the development of the ego-ideal we begin to see how it is a more complex concept than what is casually referred to as an 'ideal', and can be useful in the understanding of a broader range of psychic phenomena. Finally, I will present some evidence as to how the ego-ideal can be perceived as being 'the heir to primary narcissism'.

This paper is divided into three parts. In the first part I review Freud, so that we can see what has been the metapsychological origin of this concept, and how it changed with the evolution of his theories. In the second part, I follow the vicissitudes of the ego-ideal from infancy into adulthood. In the third part I will present some clinical material that will help to identify some of the characteristic features of ego-ideal pathology, or as Chasseguet-Smirgel calls it, "the malady of the ideal". This malady it will be seen is always closely related to variations of narcissistic states, which is why it is important to stick firmly to Freud's original conception of the ego-ideal.

\section{FREUD'S CONCEPTION}

Freud first used the term ego-ideal in 1914, in his paper On Narcissism. It developed as a continuation of his concept of primary narcissism, and the need to put the economics of libidinal flow into a logical framework. Freud described primary narcissism as, "the libidinal complement to the egoism of the instinct of self-preservation". In other words it is a reservoir of libidinal energy that has not yet been invested in anything outside the self. This "original libidinal cathexis of 
the ego", is also referred to as "Ego-Libido". Yet presence of this infantile narcissism was not readily visible in normal adults. The question then was, "What has become of their ego-libido?" Freud postulated two pathways: One part of it is cathected onto objects, starting with the primary caretaker. This Freud called "Object Libido". The remaining part is invested in the so called "Ideal Ego", which is really an ideal image of the self, the possessor of every imagined perfection. As the child develops, "he is disturbed by the admonitions of others and his own critical judgement is awakened, he seeks to recover the early perfection, thus wrested from him, in the new form of an ego-ideal." (Freud 1914,pg. 51)

This first usage of the term ego-ideal underwent changes between 1914 and 1932. In Freud's paper Group Psychology (1921) the ego-ideal was invested with the functions of, "self-observation, the moral conscience, the censorship of dreams, and the chief influence in repression." Unlike in 1914 therefore, the term now came to include what had been referred to as the "conscience", a precursor of the super-ego. Then in 1923, in his paper, The Ego And The Id, and his formulation of the structural model, the ego-ideal became synonymous with the super-ego. Finally in 1932, in the New Introductory Lectures, the super-ego was described as "the vehicle of the ego-ideal, by which the ego measures itself. . . . No doubt this ego-ideal is the precipitation of the old ideas of the parents." With the coming of the structural model in 1923 the super-ego came much more into the foreground, while the ego-ideal lost some of its original identity and was subsumed as a substructure of the super-ego.

In an attempt to maintain some clarity around the concept let me trace the development of the ego-ideal and its vicissitudes from infancy into adulthood.

\section{DEVELOPMENTAL VICISSITUDES}

At the beginning there is simply the infantile narcissistic omnipotence, which is libido cathected exclusively within self. With the emergence of separation-individuation the process of disillusionment starts. Part of the libido, nevertheless, remains cathected onto the ideal-ego, and this forms the core of the ego-ideal. Another part of the libido is cathected onto objects, the primary caretaker, the parents, leading to idealization of the love-objects, the ideal parents. Meanwhile the process of disillusionment is still continuing. The pain of this continuing narcissistic injury coincides with and stimulates the development of identificatory abilities, to regain the lost omnipotence. So the child begins to incorporate and identify with the ideal parental images, which thus become another aspect of the ego ideal; the rind around the core. Therefore making up the ego-ideal we have:

1. The image of the ideal self, which is quite primitive and exists in an unmodified form, representing the 'core omnipotence' of each one of us, and, 
2. The precipitate of the ideal parent, which undergoes further phaseappropriate modifications, most evident in the period of adolescence.

To quote Peter Blos from his paper, The Function Of The Ego-Ideal In Adolescence, "The ego-ideal is subject to qualitative and quantitative changes during the course of development. . . . The ego-ideal becomes enmeshed with new drive modalities as well as with new ego-competencies as both emerge at different developmental stages. By virtue of this fact, we can expect the ego-ideal to be drawn into the turmoil in which the libidinal and aggressive drives partake during late adolescence." (1972, pg. 95). In this period which has been referred to as the second separation-individuation, the reawakened idimpulses must look for gratification through modes that are congruent to the adolescent's reality concept. A need arises to reaffirm one's autonomy and identity, as well as to integrate oneself in some way into larger perspectives of society. This may occur through religion, politics, cult-worship, or any other group-oriented activity. There is thus a re-enactment of the ambivalence and affective confusion of a two-year-old.

Thus we see that an upsurge of id-impulses in adolescence raises the need for instinctual gratification, and reaffirmation of one's omnipotence. Parents and society once again impose restrictions on this gratification, the old narcissistic wounds are re-opened, and once more a process of disillusionment begins. Instead of identification with the ideal parents this time, the group-ideal and the sexual-ideal become the targets of identification. The object choice at this time will depend, among other things on the ego-ideal that the adolescent has carried forward from his childhood. It will also depend on the ratio of distribution of the original ego-libido between object and ego-ideal. The more the balance is tilted towards investment in the 'core-omnipotence' part of the ego-ideal, the less the energy available for modification and adaptation at this point. The adolescent searches for perfection; a perfect world, a perfect ideology, a perfect sexual experience. The fantasy is to find this perfection, to become one with it, and therefore to become as perfect as it. ". . . their belief in a perfect world is rooted in an archaic belief in parental perfection." (Peter Blos 1972)

For the emergence of a reasonably healthy adult out of this turmoil of adolescence, one has to de-cathect, to some extent, one's ego-ideal. That is, one has to learn to live with being less than perfect. The 'core omnipotence' though, always remains sacred and untouched. Winnicott in his paper on the transitional object (1953), discusses the experience of omnipotence that is allowed the infant by the mother's adaptation in letting herself be under the baby's magical control. With onset of the inevitable disillusionment, and the perception of external reality, the illusion of omnipotence is permitted to continue unchallenged in what Winnicott has termed, "the intermediate area" between the subjective and that which is objectively perceived. Derivatives of this perhaps find expression in the enriching experiences of play, creativity, love, our deep-rooted beliefs of immortality, and of eternal hope. As Lampl de-Groot 
states, "It is an important support for a man's mental balance, when his ego-ideal functions well, it's level is not too high, but high enough to strengthen the self-esteem." (1947,pg. 10)

\section{CLINICAL CORRELATES}

So what happens when that balance is lacking? In the third part of this paper we will see that it helps greatly to understand the psychic structure and psychodynamics of certain conflicts if one keeps in mind the vicissitudes of ego-ideal development. I will be looking first of all at how ego-ideal pathology influences object-choices, then how it results in disturbances of self and egostructure, which manifest in certain kinds of behavior and mental mechanisms, and also find expression within the transference. My purpose is to point out the common thread of ego-ideal pathology that links these varied clinical settings.

Annie Reich in her paper, Narcissistic Object Choice In Women, (1953) illustrates how the ego-ideal influences object-'hoices. She makes a distinction between the ego-ideal and the super-ego, stating, "The super-ego is the later, more reality-syntonic structure, while the ego-ideal is the earlier, more narcissistic one.” (1954, pg. 218). She describes two types of narcissistic object choice in women. The first, "Women who are in a particular relation of dependent subservience to one man, whom they consider great and admirable, and without whom they cannot live." In the second group are women who have, "transitory pseudo-infatuations". Their relationships are short-lived with extremes of idealization and devaluation. The defect seems to be in the function of selfesteem regulation. They use magical ways of restoring their self-esteem, that is, by forming unrealistic, intense and idealized relationships. The women are seen to derive narcissistic gratification by identification with the phallic masculinity of their sexual partners, letting their ego merge with this ego-ideal. Although this appeared as a paternal type of ego-ideal, further uncovering revealed that, "the fantasy of identifying with a phallic character was a subsequent reaction to the disappointment at the lack of a penis in the mother. It was the unrelinquished, primitive pattern of attachment to the omnipotent mother which determined their adult love-object choices." (1953, pg. 27)

Khan described a similar type of adult object relationship which he termed, "Symbiotic Omnipotence". This came up in the analysis of three of his patients who were well-functioning, superficially well-organized, and had no clear-cut symptoms. As analysis progressed, there settled a mood of inertia and helpless dependence over both patient and analyst. Any attempt to change this structure induced a reaction of panic, depression and self-pity. To quote Khan, "It is this mood of inertia, helpless dependence, and coercing me to fit in with their affectivity, that I call, Symbiotic Omnipotence." (1965, pg. 84). Dynamically it consisted of a mixture of compelling and clinging. Further Khan states, "Striking in my patients' childhood parental object relations was the intense and exclusive relationship to one parent, the mother."' $(1965, \mathrm{pg}$. 85). 
He sees in these people a need for idealization of objects because only by identifying with such idealized objects are they able to regulate their self-esteem. I see this need for Symbiotic Omnipotence as being equivalent to what Annie Reich describes as the archaic elements in the ego-ideals of her patients, their need for merging with their narcissistic object choices.

One other interesting concept that Khan brings up in this kind of ego-ideal pathology is, the "special self", being preserved through special relationships. He describes this as a "transitional object between the child's Ego and the mother." So in both Annie Reich's and Khan's patients, the function that these 'special', idealized and intense relationships serve is to preserve the integrity of this primitive and special self, hidden within the folds of an otherwise wellfunctioning psyche. A sense of recovery of the narcissistic omnipotence is achieved whenever an appropriate object choice allows one to externalize this grandiose element and then identify and merge with it.

In another paper (Khan, 1965) Khan uses this concept of the secretly preserved 'special self' to explain phobic and counter-phobic mechanisms in three of his patients with Schizoid character disorders. During their "phobic phase' these patients were withdrawn, self-absorbed, and in an inconsolable chronic anguish. Khan states that, "the role of the phobic mechanism in these patients was essentially in the service of maintaining a link with an internalized ideal state, which included the primary narcissistic self, and the idealized object." Here Khan is clearly alluding to the two aspects of the ego-ideal that I have earlier described; the 'primary narcissistic self' which is the core omnipotence, and the 'primary idealized object', which is the precipitate of the fantasized ideal parent. So in these Schizoid characters, the ego-ideal is so primitive and grandiose that the only way they were able to regulate their self-esteem was by maintaining this pathological link with their ego-ideal. The role of the counter-phobic mechanism was to allow them to create certain 'special situations' and relationships, which could further actualize their narcissistic needs. In the counter-phobic phase they showed a remarkable reversal of affects; "self-absorption changed into exteriorized enthusiasm, apathy changed to elation, instead of fantasying there emerged avid perception and action. A sense of shame about inadequacy subjectively changed to a sense of triumph and exaltation." (1965, pg. 74). These social techniques, however, always remained superficial and impersonal. The purpose was simply to create the illusion of being involved in special relationships with objects perceived as being special. This characteristic need for being special is clearly the hallmark of ego-ideal pathology. The psychopathology in these patients as in those of Annie Reich, stemmed from similarly idealized, unrealistic and intense relationships with the mother. The mother, too, in these cases nurtured such a pathological relationship by allowing herself to gratify her own narcissistic needs.

In Khan's patients, just as in Annie Reich's, the object relationships had the characteristic 'as-if' flavor. They were sudden, impulsive, intense and transient. 
Khan points out some characteristic features of this sense of being special:

1. Use of denial and splitting mechanisms.

2. Maintaining secretly idealized relationships involving displacement and reversal of affects.

3. Massive repression of aggression and rage.

4. Lack of definite establishment of the self boundaries and the experience of object and self as separate entities.

Narcissistic personality traits like those just described are not always so hidden as to be uncovered only under analytic exploration. Main pointed how in an inpatient setting one can detect ego-ideal pathology in patients who try hard to become favorites. Later, Peter Lomas, referring to such patients in his paper, "The origin of the need to be special", wrote that the trauma of these patients lay in the failure on the part of the mother (or environment) to recognize and respond appropriately to the patient's real individuality, thus fostering a craving for recognition, and a seduction by the mother to satisfy that craving through establishing a special and exclusive relationship with her, in which he feels valuable only because of this relationship.

I have thus far described how the roots of a pathological ego-ideal are usually seen to lie in a disturbed early mother-child relationship, one involving over-idealization of the love object. The shadow that follows over-idealization is always over-devaluation. That is, a child's disillusionment is going to be directly proportional to the intensity of idealization. The shift from over-idealization to over-devaluation may be accompanied by a corresponding shift in fantasy. The fantasy becomes an instrument used in the service of regaining the idealized relationship.

One of the variations of this process may result in the generation of the fantasy of the "family romance". There is a connection between this fantasy and the excessive need to preserve a sense of infantile omnipotence. Frosch (1959 pg. 506) noted, "In reaction to the disillusionment with his own, at first over-idealized parents, the individual fictionalizes his origin and creates noble parents in his family romance. He brings into being a fantasy which in many neurotics is really never totally abandoned." In such neurotics there is a predisposition to over-idealize later love objects, whenever the object choice evokes a parental transference. For example, as Frosch points out, such patients come into analysis with a readiness to over-idealize the analyst. By using this mechanism, the patient therefore attempts to involve himself in a special kind of relationship with the analyst; a relationship based on a fantasy which will then help to preserve the sense of a 'special self' as described by Khan.

So we see how immature, archaic components of the ego-ideal, when they persist in an excessive degree, can lead to different clinical presentations. In Annie Reich's female patients it is the two types of narcissistic object choice. In Khan's patients it manifests as phobic and counter-phobic mechanisms, or in 
establishing a symbiotic-omnipotent kind of relationship with the analyst. Peter Lomas points out the craving for recognition and the need to be the favorite. Finally, Frosch sees specific types of idealizing transference as being derived from the fantasy of the family romance, which again has its roots in the early over-idealization of love objects.

\section{CONCLUSION}

Freud's original concept of the ego-ideal was that it is something that we inherit from the state of primary narcissism, and the experience of omnipotence that goes along with it. It is a useful concept that can help us to understand some of the interpersonal behavior or intra-psychic fantasies that we come across in our therapeutic work. To use this concept we must keep clear in our mind the line that extends from primary narcissism to ego-ideal. One source of confusion is the allied concept of the super-ego. But there is a difference. As Annie Reich put it, "The ego-ideal expresses what one desires to be, the super-ego what one ought to be." In another way, the ego-ideal is the heir to primary narcissism, while the super-ego is the heir to the oedipal complex. My contention is that when we think of the structural model of the mind, we should not think of it only in terms of the id, ego, and super-ego, but that we should also keep in mind a fourth dimension-the ego ideal.

\section{REFERENCES}

1. Blos P: The function of the ego-ideal in adolescence. Psa. St. Child 1972; 27:93-97

2. Freud S: Family romances. Collected Papers 1909; London: Hogarth

3. Freud S: Narcissism: An introduction. Standard Edition 1914; Vol. XIV

4. Freud S: Group psychology and the analysis of the ego. Standard Edition 1921; Vol. XVIII

5. Freud S: The ego and the id. Standard Edition 1923; Vol. XIX

6. Freud S: New introductory lectures on psychoanalysis. 1932; London: Hogarth

7. Frosch J: Transference derivatives of the family romance. J Am Psychoanal Assoc 1959; 7(3):503-522

8. Hartmann H, Loewenstein R: Notes on the super-ego. Psa St Child 1962; 17:42-81

9. Jacobson E: The self and the object world: Vicissitudes of their infantile cathexis and their influences on ideational and affective development. Psa St Child 1954; 9:75-127

10. Khan M: Role of phobic and counter-phobic mechanisms and separation anxiety in schizoid character formation. The Privacy of the Self 1965; London: Hogarth, New York: Int. Univ. Press

11. Khan M: On symbiotic omnipotence. The Privacy of the Self 1965; London: Hogarth, New York: Int. Univ. Press

12. Khan M: Ego-ideal, excitement and the threat of annihilation. The Privacy of the Self 1963; London: Hogarth, New York: Int. Univ. Press

13. Lampl De Groot J: On the development of the super-ego. Int J Psycho-Anal 1947; 28:7-11 
14. Lebe DM: Female ego-ideal conflicts in adulthood. Amer J Psychoanal 1986; 46(1):22-32

15. Lomas P: The origin of the need to be special. Brit J Med Psychol 1962; 35:339346

16. Main TF: The ailment. Brit. J. Med. Psychol. 1957; 30:129-145

17. Nunberg H: The synthetic function of the ego. Int J Psycho-Anal 1931; 12:123140

18. Reich A: Narcissistic object choice in women. J Am Psychoanal Assoc 1953; $1: 22-44$

19. Reich A: Early identifications as archaic elements in the super-ego. J Am Psychoanal Assoc 1954; 2:218-238

20. Sandler J, et al: The ego-ideal and the ideal self. Psa St Child 1963; 18:139-158

21. Schafer R: Ideals, the ego-ideal, and the ideal self. Psychological Issues 1967; 5:131-174

22. Spitz RA: On the genesis of super-ego components. Psa St Child 1958; 13:375-404

23. Van den Deele L: A developmental study of the ego-ideal. Genetic Psychology Monographs 1986; 78:191-256 